Teosofia: Indonesian Journal of Islamic Mysticism, Vol. 9, No. 2, 2020, pp. 275-286

e-ISSN: 2540-8186; p-ISSN: 2302-8017

DOI: $10.21580 /$ tos.v9i2.7959

\title{
FROM HARD ROCK TO HADRAH: Music and Youth Sufism in Contemporary Indonesia
}

\author{
Muhammad Mukhsin Jamil \\ Universitas Islam Negeri Walisongo Semarang \\ mukhsin_jamil@walisongo.ac.id
}

Article history: Received: 2 July 2020, Accepted: 30 October 2020, Published: 5 November 2020

\begin{abstract}
:
Many studies on Islam in Indonesia usually focus on Islamic movements from social, economic, or political perspective. One missing viewpoint that does not get much attention or even completely ignored is the spiritual life of the Muslim youths. This study would examine and analyze the growth of the Syeikhermania and their attachment to Hadrah music of Majelis Shalawat Ahbab al-Musthofa led by Habib Syeikh Abdul Qadir Assegaf, an Arabic-descent Muslim preacher. Unlike Muslim youth organizations that are enthusiastically active in political movements that tend to be radical, Syeikhermania plays a role in creating harmony and tolerance. They transform spiritually from Hard Rock to Hadrah music. Therefore, this study disclosed the participation of the Muslim youths in the Majelis Shalawat Ahbab al-Musthofa which is motivated by the need for spiritual protection and expressing their identity as Muslim youths in contrast to the liberal and secular cultures on the one hand and fundamentalist and radicalist groups on the other hand.
\end{abstract}

Keywords: Syeikhermania, Hard Rock, Hadrah, Muslim youths, Sufism

\section{A. Introduction}

ome people think that youths usually spend their time having fun, looking for pleasure through various activities such as sports, watching music performances, and other entertaining activities. Rarely is it to find them who get involved in religious organizations or spiritual brotherhoods. This fact seems to prove the secularism thesis that religion will be human's history due to the modernization of civilization as a result of science and technological developments. ${ }^{1}$ One of the youth groups who actively get involved in religious activities is Syeikhermania. Thousands of Syeikhermania from various cities usually attend Majelis Ahbab al-Musthofa wherever it performs. They come to the event by riding motorbikes while waving flags

\footnotetext{
A. Peter and L. Berger, "Reflections on the Sociology of Religion Today," Sociology of Religion: A Quarterly Review, 2001, https://doi.org/10.2307/3712435; John Markoff, Robert N. Bellah, and Phillip E. Hammond, "Varieties of Civil Religion," Sociological Analysis, 1981, https://doi.org/10.2307/3710595.
} 
of Syeikhermania, wearing sarongs and white shirts or T-shirts with the image of Habib Syeikh bin Abdul Qadir al-Syegaf on them, the central figure of Majelis Ahbab al-Musthofa.

The youths are involved in parking the vehicles and motorcycles to avoid traffic congestion, preparing all the show equipment such as stage, sound and audio, and other supporting ornaments needed to make the event rousing. The event is usually preceded by $d h i k r$ (reciting certain prayers repeatedly to remember God), followed by reading barzanji (poetic story and biography of the prophet), and pengajian (Islamic religious sermon) accompanied with hadrah music. The youth Syeikhermania from any area then fuses into one and focuses listening to the Habib Syeikh's preaching while hopping like enjoying pop or rock music performances. They enjoy the hadrah music. During the event, a group of youths usually wave banners with messages such as "Prei dolan, shalawatan" (stop playing, go shalawat) "Syeikhermania anti kekerasan" (Syeikhermania is anti-violence), "NKRI harga mati" (The sovereignty of the Unitary State of the Republic of Indonesia is non-negotiable), and so forth. Syeikhermania has many chapters in some areas. They make and sell souvenirs and merchandise such as T-shirts, wristwatches, sarongs, praying hats, scarves, and so on. This phenomenon stimulates the increase of Muslim youth participation in the same events in various cities. The Sufism spirit expressed in hadrahtraditional music has shifted youths' attention from hard rock to hadrah music. To view such a phenomenon, this study attempts to answer the question of why the youths, especially Syeikhermania, get involved and enthusiastically attend the Majelis Shalawat Ahbab al-Musthofa by Habib Syeikh. What makes them interested to attend the event.

Indonesian Muslim youths have been studied from various perspectives. Some studies analyze their movement and activism and their influence on youth's lives. ${ }^{2}$ Most studies so far just focus on youths' participation in trans-national Islamic movements such as Hizbut Tahrir Indonesia, Jama'ah Tabligh, Tarbiyah Movement, including favoring their political party called Partai Keadilan Sejahtera (Prosperous Justice Party). Besides, some studies on youths' participation in the religiously affiliated military such as Laskar Jihad, and Islamic Defenders Front (FPI, Front Pembela Islam). Some others study traditional Sufism, particularly that is related to some charismatic figures such as Habib. ${ }^{3}$ The studies focused on the popularity of

2 Greg Fealy and Sally White, Expressing Islam: Religious Life and Politics in Indonesia, Expressing Islam: Religious Life and Politics in Indonesia, 2008; Noorhaidi Hasan, Laskar Jihad, Laskar Jihad, 2019, https://doi.org/10.7591/9781501719226; N Kailani, “Aspiring to Prosperity: The Economic Theology of Urban Muslims in Contemporary Indonesia" (University of New Shout Wales, 2015); Syamsul Rijal, "Indoctrinating Muslim Youths: Seeking Certainty Through An-Nabhanism," AlJami'ah: Journal of Islamic Studies, 2011, https://doi.org/10.14421/ajis.2011.492.253-280; Minako Sakai, "Preaching to Muslim Youth in Indonesia: The Dakwah Activities of Habiburrahman El Shirazy," RIMA: Review of Indonesian and Malaysian Affairs, 2012.

3 I Alatas, Securing Their Place: The Habaib, Prophetic Piety and Islamic Resurgence, MA Thesis (National University of Singapore, 2008); A. Zamhari and J.D. Howell, "Taking Sufism to the 
Habib as the descendant of the Prophet from the Hadramaut chain among the youths, youths' experiences in following the Islamic learning forum as well as factors prompting them to participate in the Majelis Ta'lim (Islamic-learning forum) taught by Habib. Alatas (2009), and Zamhari and Howell (2012) emphasize the growth of urban Sufism is a factor describing the development of the Majelis Ta'lim followed by young people. Meanwhile, Rijal (2020) explains why a greater number of non-sayyid Muslim youths join the Majelis Ta'lim in the last decade. Following the argument of Asep Bayat (2010), in his study on Muslim youths in Iran and Egypt, Rijal (2020) argues that Indonesian Muslim youths who participate in the Majelis Ta'lim and Habaib's religious forum is not only to fulfill their spiritual needs but also to express themselves as pious people amidst the uncertainty, unsatisfactory, and limited space of Jakarta for urban youths. A study of Ahbab al-Musthofa by Nur Rosyid (2012) concludes that there is a process of relational change into commoditization which is called a "religious franchise" in the community of Ahbab al-Musthofa, as can be seen from the highly standardized events and products such as stage, audio, and visual types of equipment, etc. It is, therefore, whether realized or not, the global business logic of franchise influences the contextualization of shalawat tradition. ${ }^{4}$

Different from previous studies, this study will examine Syeikhermania as a subcultural phenomenon with its unique socio-cultural functions. Syeikhermania is a community member of the Majelis Ahbab Al-Muthofa (AM) which uses Hadrah music in its religious event. Ahbab Al-Muthofa's headquarter is in Surakarta, Central Java. AM usually performs in cities and towns throughout the country. The development of AM is followed by the establishment of Syeikhermania nationwide. Syeikhermania defines itself as the follower of Syaikh Abdul Qadir Assegaf. They perform traditional rituals such as tahlilan, yasinan, and mauludan as well as shalawatan. They declare that they are the Prophet's lovers who practice shalawat. After observing and interviewing some Syeikhermania, they identify themselves as the follower of moderate Islam (tawasuth) and tolerant (tasamuh), namely ahlusunnah waljamaah. They distinguish themselves from other groups with extreme ideologies such as Hizbut Tahrir Indonesia and other Salafi-Wahabi groups who are against the tradition and rituals that they practice. This study was conducted in 2018-2019 by observing the Majelis Ahbab alMustofa and conducting deep interviews with some Syeikermania activists and the officers of AM.

Streets: Majelis Zikir and Majelis Salawat as New Venues for Popular Islamic Piety in Indonesia," RIMA: Review of Indonesian and Malaysian Affairs, 2012; Julia Day Howell, "Modulations of Active Piety: Professors and Televangelists as Promoters of Indonesian 'Sufisme," in Expressing Islam: Religious Life and Politics in Indonesia, 2008, https://doi.org/10.1355/9789812308528-007; Rijal, "Indoctrinating Muslim Youths: Seeking Certainty Through An-Nabhanism."

4 Mambaul Ngadimah, "The Spirituality of Mafia Shalawat: A Case Solution of Modern Society", In IOP Conference Series: Earth and Enviromental Science, 175:012181. IOP Publishing, 2018, 3. 
Besides, several publications on Ahbab al-Musthofa are also taken as sources of data. This study employs a qualitative method. To attain a good and deep understanding, this study combines text analysis and ethnography. In the beginning, this study discusses the profile of Habid Syeikh Abdul Qadir Assagef as the central figure of AM, the role model of Syeikermania. In this part, the author analyses the establishment of the Habib's Majelis Ta'lim and its development including its popularity and how it could attract a large number of Muslim youths. The second part will discuss Syeikermania in terms of the history and social background of its members. The third part elaborates the cultural and structural context as a framework of youths' involvement in Hadrah music. The fourth part examines the perspective and perception of Syeikhermania on Majelis Ahbab Al-Musthofa with its musical instruments as a means of da'wah. Meanwhile, the last will analyze the meaning of Syeikhermania's participation in the da'wah forums.

\section{B. Habib Syeikh Abdul Qadir Assegaf and Ahbab al-Musthofa}

Habib Syeikh bin Abdul Qadir Assegaf, well known as Habib Syeikh, is the founder of Majelis Ta'lim Ahbab al-Musthofa. He was born in Solo, Central Java on September 20, 1961. He has 16 siblings from his parents, Abdul Qadir Assegaf and Syarifah Bustan Al-Qadiri. Syeikh here is not a Sufistic title but is a nickname given by his father. In an interview on Al-Hijra Television of Malaysia (2015), Habib Syeikh stated that:

"My name, Syeikh, is not a teacher title because I am not. When I was a kid, my father called me Syeikh, and people called me Syeikh bin Abdul Qadir Assegaf. Some people even call me Syeikh Abdul Qadir Assegaf, thinking that I am a teacher. No, Syeikh is my real name.

Habib Syeikh learned Islamic knowledge from his father who was an imam at Assegaf mosque in Solo. As his father thought him, Habib Syeikh follows Syafi'i legal school. In terms of theology, he follows the Asy'ari school, and in Sufism, he follows Al-Ghazali. After his father passed away when he was 20 years old, Habib Syeikh went to some teachers such as his uncle, Habib Ahmad bin Abdurrahman Assegaf. Also, he learned from a charismatic figure in Solo, Habib Anis bin Alwy Al-Habsyi, the author of Simtud Duror. After learning from his father, uncle, and Habib Anis Al-Habsyi, he had already enough knowledge. He began to preach and perform on Majelis Shalawat. Finally, Habib Syeikh became a preacher familiar among the religious community particularly those who love Hadrah music. His excellence in shalawat recitation and creating poetic lyrics could attract the youths. His heavy, charismatic, and unique voice hypnotize thousands of his followers listening to him reciting/singing shalawat. Following his teacher's preaching method, Habib Syeikh initially preached from one village to another in remote areas. Habib Syeikh succeeded to overcome obstacles he faced in his early career. As time goes by, he is now a magnet due to his Majelis 
Shalawat event held in many cities in Indonesia. His regular event, Majelis Ahbab alMusthofa, is held in Solo, Central Java.

Ahbab al-Musthofa is a Majelis Ta'lim in which Habib Syeikh dedicates himself to ease his followers in learning and practicing the life of the Prophet. The Majelis was founded in 1998, from a Simthud Duror forum which took place in Mertodranan village, Solo city. AM is now held regularly in other towns such as Purwodadi, Kudus, Jepara, Sragen, Yogyakarta, Semarang, and occasionally in some other big cities like Jakarta. Besides organizing Majelis Shalawat, AM also uses communication technology as a new way to promote its agendas and to deliver a da'wah to a broader audience. Its website, Ahbab al-Musthofa, is an important medium to promote figure, ulama, and its Islamic religious forum. The home page of the website, for instance, publishes several pictures of Habib Syeikh and other ulama wearing various clothing, showing the nuance of traditional Islam. The pictures also show some activities such as praying and preaching. Some other pages of the website provide organization profile, programs, and schedule, pictures of events, the recorded shalawat recitation of Habib Syeikh, prayers, and links to social media, radio, youtube channel, and some live streams.

In every event, Habib Syeikh mostly emphasizes more on morality and Sufism practices than rigid legal doctrines of Islam. This is what distinguishes this Majelis from other global Muslim movements such as the Salafi-Wahabi group which strictly holds and teaches its followers a set of theological and legal doctrines. On several occasions, Habib Syeikh invites the audience to be a pious person by being obedient in performing prayers, doing good deeds, and avoiding evils. Those messages were not only delivered only in his speeches but also through his music lyrics. Many of his followers felt being guided, serenity, and peace as well as happiness and entertainment by attending Majelis Shalawat Ahbab al-Musthofa.

\section{Hard Rock and Hadrah Fans Club}

The music groups usually have fans; some of them are fanatic which then establish a community such as Orang Indonesia (OI) for the fans of Iwan Fals, Baladewa of Dewa 19, Fans Rhoma Irama dan Soneta Group (FORSA), and Slanker of Slank. The members of these music groups have different social backgrounds based on the music genre they like. Similar to those fans group, the followers of Majelis Shalawat Ahbab al-Musthofa lead by Habib Syeikh, are mostly the youths who then established a group called Syeikhermania. The media of da'wah used by Habib Syeikh is Hadrah (Shalawatan) music that is composed of verses/lyrics containing moral values and advice that want to create a distinct segment. On the Youtube channel, there are hundreds of his shalawat videos with millions of viewers. Habib Syeikh also released several (at least 10) shalawat albums. Many of them are in the Arabic language and some of them are in Bahasa and Javanese languages. 
According to his followers, Syeikhermania is a community that loves reciting shalawat for the Prophet Muhammad sincerely because of the encouragement of Habib Syeikh as the leading figure of Majelis Ahbab al-Musthofa. The name "Syeikhermania" is derived from the name of Habib Syeikh. They named it Syeikhermania as they feel that Habib Syeikh excites them by his advice to always recite shalawat upon the prophet and to leave the worldly pleasure. ${ }^{5}$ Syeikhermania was established in 2009 by Muhammad Miftahudduha (Gus Duha). Most of Syeikhermania's members are teenagers, male and female. They are those who seek self-identity and need guidance. In their opinion, Habib Syeikh can guide them by his affection for the teenagers so that they feel comfortable with him.

The establishment of Syeikhermania is different from the fanbases of other music groups in Indonesia. A music fan community is usually established by the music management to organize the fans as the market. Syeikhermania was established neither by Habib Syeikh nor his management but it was naturally established and developed. Furthermore, Habib Syeikh did not even know about the establishment of the Syeikhermania community. In an interview on TV9 (2015) Habib Syeikh stated that:

“After my da'wah was spread, Syeikhermania unexpectedly emerged. After thousands of people attended, there was suddenly Syeikhermania. I was wondered, who initiated this? I did not even know. Syeikhermania was established by itself. It was not my initiation. ${ }^{6}$

On the other hand, the founder of Syeikhermania stated that Habib Syeikh once prevented the establishment of this community. In 2009, Habib Syeikh asked some Syeikhermania who came from different towns to know how big the community was. Habib Syeikh asked them to disband this community. The members of Syeikhermania were estimated, at that time, around 16.000. That number is now predicted to grow up to around hundreds of thousands considering the chapters of Syeikhermania spanning from Aceh to Papua. One important point to remember by Syeikhermania is that he did not want this community is similar to youth communities which tend to make wrongdoing or do useless things. His worry is understandable since many music group communities only have fun and useless activities. Hard Rock music fans, for instance, often get involved in fights and quarrel during the concert. Habib Syeikh was also afraid that this community would be used for political interest.

Yet, Syeikhermania preserves this community since they believe that the community is intended to gather the youths to do positive activities and they are eager to handle this. At last, Habib Syeikh accepted it with some conditions: 1) Syeikhermania must not get involved in politics, 2) Syeikhermania must not be overhyped. 3. Syeikhermania is not an uncontrolled community. Up to now, Syeikhermania has spread nationwide and has chapters in many cities and towns, and

5 Sokhi Huda, Tasawuf Kultural: Fenomena Shalawat Wahidiyah, (Yogyakarta: LKiS, 2008), 122.

6 Interview with Habib Syeikh, 2015. 
even neighborhood countries. The members are not only limited to the youths. Many young people from various cities who are commonly identified as the son of modern culture with its arts and music join Syeikhermania as a traditional community with its unique music genre; from a glamorous lifestyle to a religious one, from pop music to shalawat, from hard rock to hadrah.

\section{Music and Youth Sufism}

The Majelis Shalawat Ahbab al-Musthofa which is usually attended by a huge number of Sekhermania is a fascinating phenomenon. Hundreds of thousands of people crowd the event whatever the condition is. Rain will not make anyone leave the event. They are faithfully waiting for Habib Syeikh to recite shalawat and giving godly counsel. Cars, buses, trucks, motorbikes, and other kinds of vehicles with stickers and writings of Syeikhermania make a long line of a parade on road. In the area of the event, some people also open many stalls that look like a market. The Majelis Shalawat Ahbab al-Musthofa is usually conducted in the evening, after Isya's prayer around 20.00 until 23.00. Habib Syeikh's presence is always waited by thousands of audiences and therefore, when He arrives, audiences enthusiastically welcome him. To calm down the crowd, in the beginning, Habib Syeikh invited them to recite shalawat upon Prophet Muhammad PBUH.

"Let us recite shalawat upon the most honored man on earth. Therefore, we must recite it in an honor way too; no smoking, no need to stand up and jump! Just be seated!"

To start the agenda, Habib Syeikh usually explains briefly the biography of the prophet. Anytime, the name Muhammad is called, the audiences reply with shalawat loudly. Amidst the crowd, there are flags with the logo of Syeikhermania from various chapters such as Sykhermania Surabaya, Cirebon, Semarang, Kediri, Lamongan, Gresik, Aceh, and Lampung. There are also flags with logos of Nahdlatul Ulama (NU), political parties, and football clubs. Flags of Slankers (fans of Slank) and OI (the fans of Iwan Fals) are also found. Everyone enjoys the music beat and Hadrah played by the AM's group with the high quality of sound equipment. Following that, Simtud Duror, a work by Habib Ali bin Muhammad Al-Habsyi, is also recited. It is then followed by singing several Javanese songs such as padang bulan and kereta jawa. In between, Habib Syeikh delivers moral advice and the biography of the Prophet. The shalawat and Hadrah music are supported by traditional Arabic music instruments such as terbang, jidur, and tambourine. Some of the group members play roles as backing vocalists of Habib Syeikh in reciting shalawat and other proses and poetries. AM's musical performance is an important part of the event.

Therefore, Habib Syeikh composed several songs in Javanese and Indonesian languages which were recorded and sung on many occasions. During the performance, Syeikhermania wave flags or raise their hands and move them right and left enjoying 
the Hadrah music performance as in any other concerts. Habib Syeikh then becomes not only the leading figure of AM but also the superstar among Syeikhermania. Syeikhermania describes him as a modest, patient, gallant, and charismatic person. His good posture, melodious baritone voice, and good appearance are the attractive factors of Syeikhermania. Syeikhermania's reaction to the hype shalawat music performance with the popular and charismatic figure, Habib Syeikh with his powerful voice, is not different from how other fans enjoy their idols' performances such as pop stars or football clubs. To prevent the quarrel in the crowds, Habib Syeikh always reminds the audience not to bring the political party's flags in the Majelis. At the end of the agenda, Habib Syeikh often invites the audience to rise and sing the national anthem, Indonesia Raya, by conveying messages before singing "we must show up that we are Muslim rahmatan lil 'alamin, a mercy for all creation, not Muslims who offend others".

Online media managed by Syeikhermania are also interesting to observe. Their official website, Facebook, Twitter, Instagram play important roles in promoting and sharing the information about Habib Syeikh and his activities with Majelis Ahbab alMusthofa as well as religious quotes and advertisements of Syeikhermania merchandises. The new media and social media also provide informal connections among the AM's followers and Syeikhermania. Through social media, the organization committee can also communicate and maintain a closer bond with Syeikhermania. Also, in social media, Syeikhermania can tell stories and experiences of joining Majelis Shalawat Ahbab al-Musthofa, discusses religious knowledge, and share the AM's upcoming events. With social media, they also can mobilize Syeikhermania and other Muslim youths to attend the Majelis. They also often follow up the discussion on social media by meetings in Syeikhermania offices and invite other Habibs (the descendant of the prophet) and AM's committee. In this small meeting, they also read maulid for social and religious purposes such as asking for protection and blessing from God in their lives. The participants experience a deeper feeling when reciting the maulid. Therefore, the Sufism rituals and discussions become more intense.

\section{E. Syeikhermania as a Subculture}

Syeikhermania is a subculture. Started from the small Majelis Ahbab alMusthofa in one of the Javanese cultural centers, in Solo, Syeikhermania spread out nationwide, in cities and towns. Habib Syeikh and his activities not only influence people in Java, where Habib Syeikh come from, but also many cities in Indonesia and abroad such as Brunei Darussalam, Malaysia, and Singapore. As a subculture, Syeikhermania has five functions: First, the function of a magical solution for socioeconomic structural problems. Syeikhermania's presence at the Majelis Shalawat Ahbab al-Musthofa is motivated by the encouragement they get during the event. They expect to get life motivation to face challenges in their lives. In every events, the participants can sell various products to other participants. The second function is a collective identity which is different from that in schools and workplaces. As a sub- 
culture, the members of Syeikhermania show their identity through lifestyle, or certain symbols such as clothes, music, and behavior. Sarong, white shirt, jacket, flag, and other attributes of Syeikhermania are symbolic expressions to strongly show their identity as loyal members of Syeikhermania.

The third function is space-winning and alternative narration for social reality. The fact that the contemporary Muslim community experiences polarization and the domination of liberalism, intolerance, and terrorism issues. What Habib Syeikh does is a smart effort from the cultural Islam perspective. In that context, the Majelis Shalawat conducted by Habib Syeikh supported by Syeikhermania is effort to unite the Muslim community from various organizations, political parties into one community, namely "The Lover of the Prophet" which has a message of peaceful Islam; Islam rahmatan lilalamin. This, at the same time, is an alternative for Islamic discourse that is different from others which tend to be more intellectual and are spread in academic forums such as seminars and classes, or socio-political forums which gives a stereotype to the Muslim community for being polarized and disunited. Imaduddin's perspective, for instance, relates Syeikhermania with nationalism education. ${ }^{7}$ The fourth function is to give more meaningful free time. Some people assume that subculture is a negative activity. Syeikhermania is an example of a positive subculture. Syeikhermania is different from motorbike gangs, underground music fans, homeless people, etc. The number of participants which reaches $10.000-100.000$ in every regular event of 2-3 hours shows the meaningfulness of the events for the audience.

The fifth function is as a complementary solution for the dilemma of existential identity. Modernity brings changes and causes an identity crisis for some people. Traditional groups and young urban Muslims in need of spirituality find a "common house" to shelter their existence (Sobirin, 2019). In this context, Habib Syeh with his Majelis Shalawat plays a role which is called by Clifford Geertz (1960) as cultural brokers and Hiroko Horikoshi (1987) as "change filter." 8 As a cultural broker, Habib Syeikh is an ulama who has power and strong influence in the local system. Even, Wicaksono (2019) identifies the power and influence of Habib Syeikh as hegemony. As a knowledge transmitter, Horikoshi views Habib Syeikh with his Majelis and Syeikhermania as a means and the filter of cultural change who possesses the power to decide values and behavior, which one is allowed and forbidden to do, for his followers and religious community. ${ }^{9}$ As a community, on one side, Syeikhermania is a

7 Imaduddin Imaduddin, "Nilai Pendidikan Islam Pada Komunitas Majelis Ṣalawāt Syekhermania Di Mataraman Jawa Timur dalam Menumbuhkan Nasionalisme," Jurnal Pendidikan Islam, 2020, https://doi.org/10.38073/jpi.v9i1.200.

8 Sister Mary William and Clifford Geertz, "The Religion of Java," The American Catholic Sociological Review, 1961, https://doi.org/10.2307/3708141; H Horikoshi, Kyai dan Perubahan Sosial, Translatio (Perhimpunan Pengembangan Pesantren dan Masyarakat, 1987).

9 Ferri Wicaksono, "Kiai Kharismatik dan Hegemoninya (Telaah Fenomena Habib Syech Bin Abdul Qadir Assegaf)," Jurnal Pemerintahan dan Politik, 2019; Horikoshi, Kyai dan Perubahan Sosial. 
typologically unique religious-cultural group that can be described as Santri who combines two subcultures, namely the loyal music fan and fanatic football fan. This is evidenced by the fact that many Sykhermania are football club fans and/or music group fans. The flexibility of "shalawatan" and "music performance" gives Habib Syeikh benefits. So, it is no wonder that in the country, he is often invited to Majelis Shalawat, but in Singapore, he was invited by the Muslim Community in Geylang Stadium to perform a music concert.

\section{F. Conclusion}

This article discusses Syeikhermania as the followers of the Majelis Shalawat Ahbab al-Mushtofa under the leadership of Habib Syeikh in terms of the socioreligious transformation in contemporary Indonesia. Focusing mainly on the Majelis Shalawat which is supported by traditional Arabic music instruments, this study discovered the strategy and the cultural approach which succeeded in attracting a social segment of the Muslim youths. Their intense and routine presence in the Majelis Shalawat has transformed the identity of traditional santri and young urban Muslims as a subculture. As the subculture, Syeikhermania, has some functions such as magical solution function for social and economic issues, alternative collective-identity function for young people who love music, the function of space winning as an alternative narration among liberal and radical Islam, the function of more meaningful free time activities, and the function of complementary solution for the dilemma of existential identity issues of Muslim youths amidst identity crisis caused by modernity.

This study found that ritual and religious tradition can be mediated through pop culture whose markets are Muslim youths with different social backgrounds, traditionalist and middle-class urban Muslims. Preaching with the musical performance gained massive support from any circle of the Muslims. It is seen from the growth of Syeikhermania in cities and towns in Indonesia. Accommodating modern instruments and performing traditional rituals is an appealing factor to attract society's participation in the Majelis Shalawat. The touch of modernity to the traditional Muslim community in villages such as information and communication technology particularly social media and the growth of urban Muslims who need religious spaces to express their aspiration make the religious event with music performance accommodating modern nuance with appeal and piety gain more and more place in the heart of Indonesian Muslim community. By employing modern media, AM succeeded to promote and popularize the tradition and gained high appreciation from society. 


\section{Bibliography}

Alatas, I. Securing Their Place: The Habaib, prophetic Piety and Islamic Resurgence (MA Thesis). The National University of Singapore, 2008.

Fealy, G., \& White, S. Expressing Islam: Religious life and politics in Indonesia. In Expressing Islam: Religious Life and Politics in Indonesia, 2008.

Hasan, N. Laskar Jihad. In Laskar Jihad, 2019. https://doi.org/10.7591/9781501719226

Horikoshi, H. Kyai dan Perubahan Sosial (Translatio). Perhimpunan Pengembangan Pesantren dan Masyarakat, 1987.

Howell, J. D. Modulations of active piety: Professors and televangelists as promoters of Indonesian 'Sufism. In Expressing Islam: Religious Life and Politics in Indonesia. https://doi.org/10.1355/9789812308528-007, 2008.

Huda, Sokhi. Tasawuf Kultural: Fenomena Shalawat Wahidiyah, Yoyakarta: LKis, 2008.

Imaduddin, I. Nilai Pendidikan Islam pada Komunitas Majelis Șalawāt Syeikhermania di Mataraman Jawa Timur dalam Menumbuhkan Nasionalisme. Jurnal Pendidikan Islam, 2020. https://doi.org/10.38073/jpi.v9i1.200.

Interview with Habib Syeikh. Interview with Habib Syeikh, 2015.

Kailani, N. Aspiring to Prosperity: The Economic Theology of Urban Muslims in Contemporary Indonesia. University of New Shout Wales, 2015.

Markoff, J., Bellah, R. N., \& Hammond, P. E. Varieties of Civil Religion. Sociological Analysis, 1981. https://doi.org/10.2307/3710595.

Ngadimah, Mambaul. The Spiritualty of Mafia Shalawat: A Crisis Solution of Modern Society, UK: IOP Publishing, 2018.

Peter, A., \& Berger, L. Reflections on the sociology of religion today. Sociology of Religion: A Quarterly Review, 2001. https://doi.org/10.2307/3712435.

Rijal, S. Indoctrinating Muslim Youths: Seeking Certainty Through An-Nabhanism. Al-Jami'ah: $\quad J$ Journal of Islamic 2011. https://doi.org/10.14421/ajis.2011.492.253-280

Sakai, M. Preaching to Muslim youth in Indonesia: The da'wah activities of Habiburrahman El Shirazy. RIMA: Review of Indonesian and Malaysian Affairs, 2012.

Sobirin, Mohamad. "Negotiating Tradition and Innovation Upon the CrossGenerational Art of Singiran: Improvisation, Cultural Identity, and Millenial Community". Teosofia: Indonesian Journal of Islamic Mysticism, Vol. 8, No. 1, 2019, 71 . 
Wicaksono, F. Kiai Kharismatik dan Hegemoninya (Telaah Fenomena Habib Syech bin Abdul Qadir Assegaf). Jurnal Pemerintahan dan Politik, 2019.

William, S. M., \& Geertz, C. The Religion of Java. The American Catholic Sociological Review, 1961.

Zamhari, A., \& Howell, J. D. Taking sufism to the streets: Majelis zikir and majelis salawat as new venues for popular Islamic piety in Indonesia. RIMA: Review of Indonesian and Malaysian Affairs, 2012. 